Proc. Estonian Acad. Sci. Geol., 1992, 41, 3, 115-123

UDC $551.72(47-15)$

Enn PIRRUS*

\title{
FRESHENING OF THE LATE VENDIAN BASIN ON THE EAST EUROPEAN CRATON
}

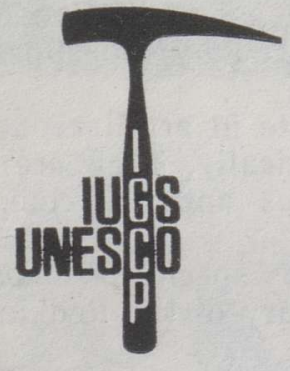

GLOBAL

Abstract. The paper gives a survey of the distribution of fossils in the late Vendian sequence, its relations with the authigenic minerals reflecting the sedimentary conditions of the host rocks, and their geochemical and structural characteristics. The data obtained indicate an extensive freshening of the Kotlin basin on the East European Craton.

The data are necessary to understand problems of global paleogeography, studied also within the framework of the new international project No. 319 "Global Paleogeography of Late Precambrian and Early Paleozoic."

\section{PALEOGEOGRAPHY}

The Upper Vendian terrigenous sediments, widely distributed in the northwestern part of the East European Craton, have mostly been treated as being of marine origin. This conception is based on the great horizontal extent and facies characteristics of rocks. There are, however, several specific features which do not fall in with this treatment. In particular, this concerns the late Vendian Kotlin Stage. Compared to the underlying Redkino and Drevliany stages and to the overlying normal marine Rovno and Lontova stages, which the present author considers already to be of Cambrian age, it has several paleontological, structural, mineralogical, and geochemical characteristics indicating the formation of this sedimentary complex in a somewhat fresher environment than the normal one. As it is rather difficult to find out the reasons of such an extensive freshening, this paper concentrates mainly on the features supposed to be indispensable for the late Vendian paleogeographic reconstructions.

The East European Vendian sequence is characterized by a peculiar distribution of fossils. Almost all fragments of Vendian multicellular soft-bodied organisms collected mainly from the regions of Podolia and the White Sea originate in the sediments of the lower half of the Upper Vendian, which in the stratigraphic schemes accepted is treated as the Redkino Stage (Великанов et al., 1983; Стратиграфия..., 1979; Федонкин, 1987). The overlaying Kotlin Stage is predominantly represented by grey, thick-bedded clays intercalated with siltstones and sandstones almost devoid of these fossils (Plates I and II), although the preservation

* Eesti Teaduste Akadeemia Geoloogia Instituut (Institute of Geology, Estonian Academy of Sciences). Estonia pst. 7, EE0105 Tallinn, Estonia. 
conditions should have been here as good as in the lower unit. The Kotlin Stage, however, is characterized by a rich algal complex, mostly represented by Vendotaenia (Гниловская et al., 1988). The latter appears at the lower boundary of the stage and rapidly disappears in the Rovno Stage of the overlying Cambrian. The algal complex of the Redkino Stage is more primitive occurring only in thin argillaceous interbeds, lithologically resembling the Kotlin rocks. Thus, their distribution is relatively well controlled by sedimentary conditions.

Trace fossils are distributed in the same way: they appear in the Redkino Stage and are there numerous and diverse (Fig. 1), but they are represented by primitive forms, like burrowing organisms, which lived in the upper sediment layer and used the peristaltic mode of horizontal locomotion only. In the Kotlin Stage, their abundance and diversity decrease abruptly; rare transitional forms occur mainly in Podolia. In the northwestern part of the platform (the Baltic, Byelorussia, and other regions) they are missing completely. At the transition to the Cambrian, an abrupt quantitative as well as qualitative change takes place in ichnocommunities. It is characterized by the appearance of vertical burrowing organisms.

The horizontal ichnites fixed by dispersed pyrite in argillaceous sediments have not yet been interpreted paleontologically. They are found only in the Redkino, Rovno, and Lontova stages and are completely lacking in the Kotlin Stage.

Only acritarchs, which are mainly represented by species of Leiosphaeridia, do not show distinct changes on the boundary of the Redkino and Kotlin stages.

The distribution of fossils needs further investigation. It is particularly significant for distant stratigraphical correlations to avoid serious errors in stratigraphy as well as in the study of the evolution of fossil communities.

Investigation of the Vendian sediments in the northwestern part of the East European Craton independently of paleontological material has allowed of the conclusion that the Kotlin sedimentation took place not in marine but in brackish environments (Менс and Пиррус, 1974). This conclusion was based on the high kaolinite content in the mineralogical composition of the red-coloured beds bordering the grey clay bed from above as well from below. The Kotlin Stage has not yielded glauconite and phosphatic nodules occurring in the overlying (Lower Cambrian) and underlying (Redkino Stage) beds. Pyrite admixture, showing the sulphate reduction characteristic of marine sediments, is also lacking.

\section{PLATE I}

Characteristic fossils from the late Vendian sediments of the north-west of the East European Craton.

1, 2 - Scarce imprints of unidentified soft-bodied organisms from the Kotlin Stage $(1$ - diameter $6 \mathrm{~mm}$, Kunevichi borehole, depth $328.8 \mathrm{~m} ; 2-$ magnification $\times 1.5$, Kunevichi borehole, depth $345.0 \mathrm{~m}) ; 3$ - accumulation of the alga Vendotaenia on a bed surface, natural size, Maloshaty borehole, depth $225.0 \mathrm{~m} ; 4-$ irregular sapropel film formed of algal remains on a bed surface - a characteristic feature of Kotlin clays, natural size, Maloshaty borehole, depth $224.0 \mathrm{~m} ; 5,6$ - the only horizontal burrow recorded from the Kotlin Stage of Estonia, views from above and from the side, natural size, Purtse borehole, depth $138.0 \mathrm{~m} ; 7$ - fine pyritized trace fossils in normal marine clays of the Redkino Stage, natural size, Pasha borehole, depth $260.3 \mathrm{~m}$, 
Plate I
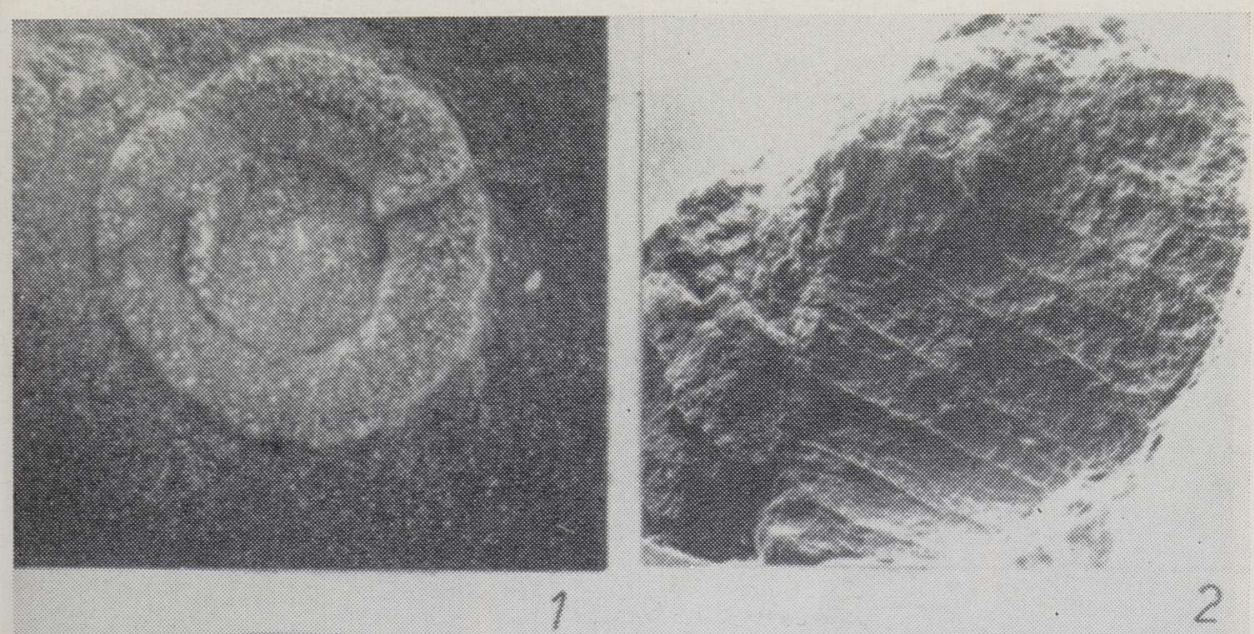

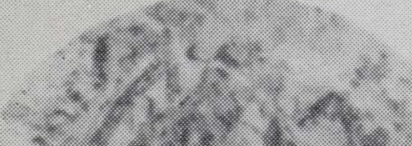

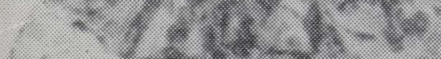

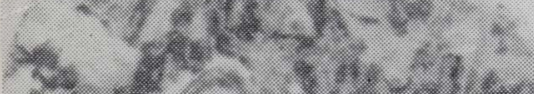

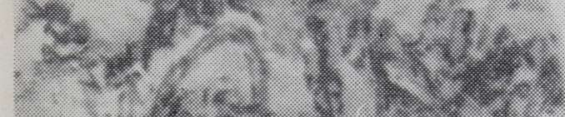

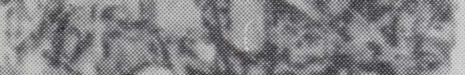
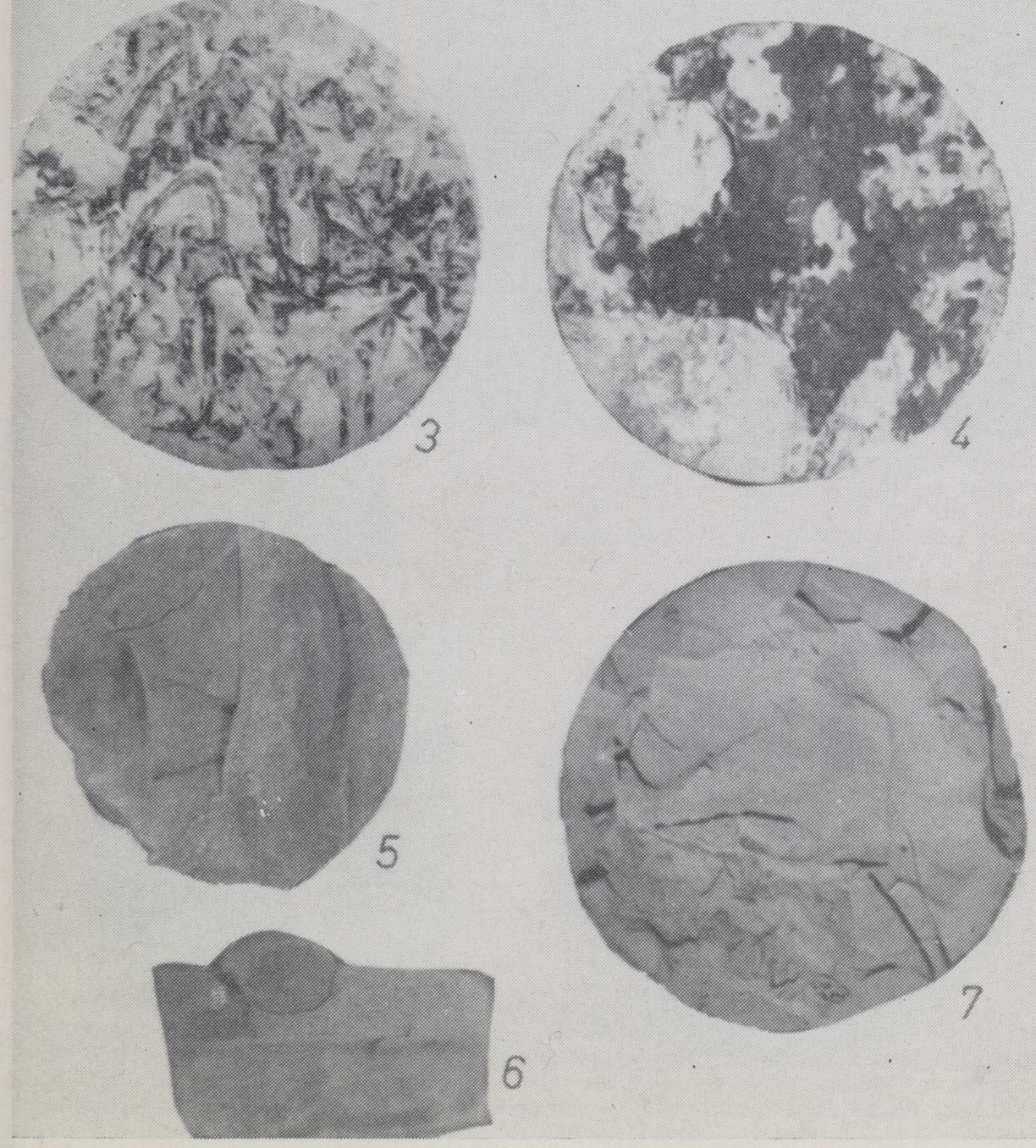

6 
Plate II

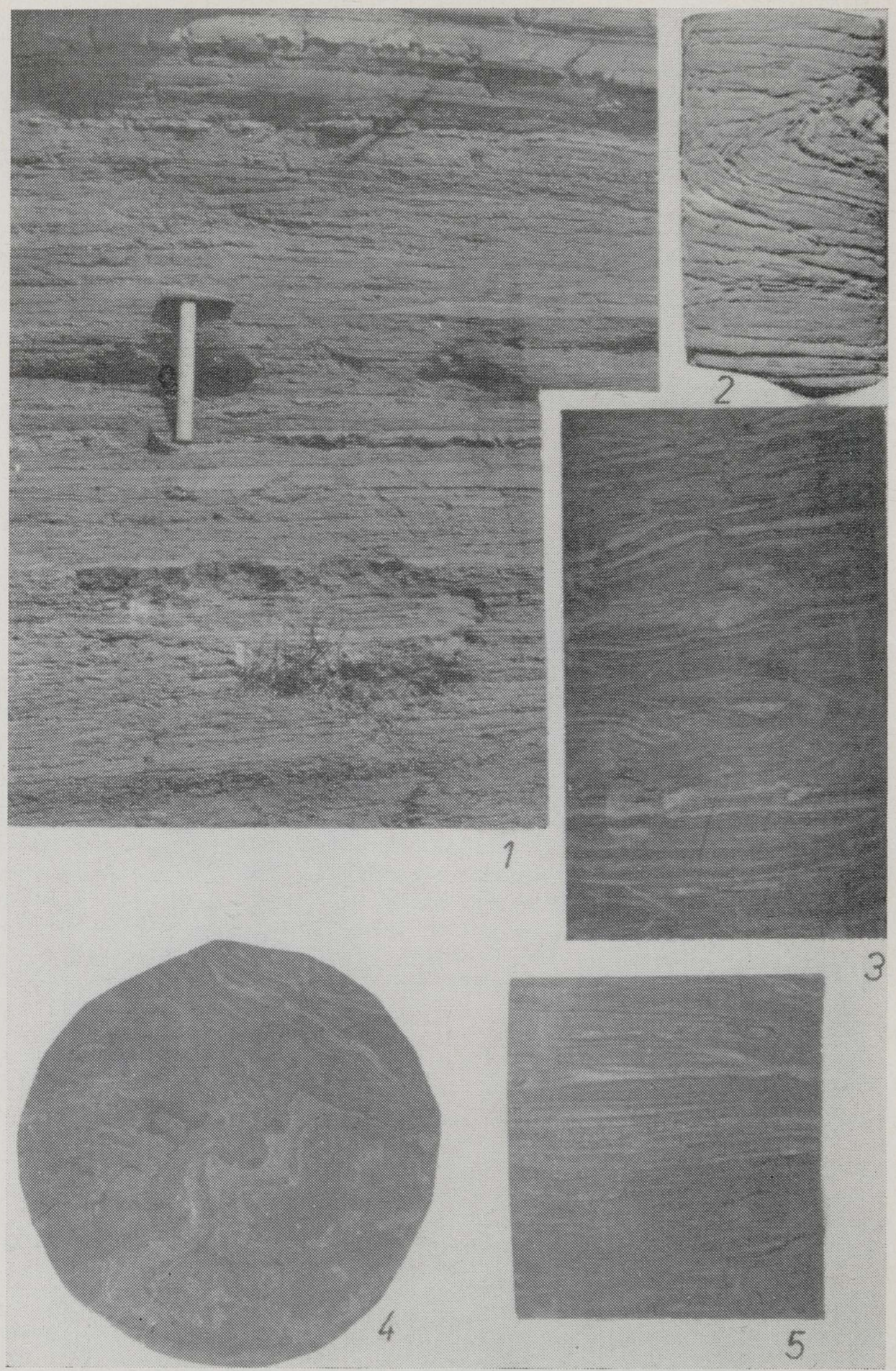


The above-said is in good accordance with the structural characteristics of Kotlin clays. Unlike typical marine clays, which lack thin bedding due to slow rate of sedimentation, coagulation of colloidal particles, and wave activity, the Kotlin clays are characterized by an extremely distinct bedding similar to glacial varved clays. They are represented by rhythmic alternation of $0.5-0.8 \mathrm{~mm}$ thick pairs of thin clay layers and more silty laminae. The lamination is complicated by the occurrence of black organic films of plant origin on clay surfaces. Such an alternation is regular and continuous throughout the sequence and can be explained only by seasonal changes in the sedimentation regime. If this hypothesis proves correct, we should find out the factors which could have caused the high sedimentation rate of fine-dispersed clay material far from the mainland. The thickness of the seasonal layers suggests that the sedimentation rate of Kotlin clays is about $5 \mathrm{~m}$ per 10000 years. It is extraordinarily high for clayey deposits.

The study of present-day sedimentary conditions has permitted to explain this phenomenon by sedimentation in the melt water zone of the glaciation areas. The formation of the sedimentary material in source areas is represented by a distinct annual cycle. The inflow of material stopped due to winter freezing of aquifers and source areas, but started again very abundantly in summer. Powerful melt water currents including material disintegrated earlier carry it into the sedimentary basin. Fresh-water masses prevent clay particles from rapid coagulation permitting their transportation over long distances. As a rule, in the glaciation areas the water is distinctly stratified into lower, little moving water masses with a permanent temperature of $+4{ }^{\circ} \mathrm{C}$ and a thin surface layer cooled down by melting. This enables the distribution of the so-called clay-rich glacier milk over very large areas. In these conditions the highly dispersed sedimentary material becomes completely differentiated: sandy and silty particles fall to the bottom rapidly, while clay particles do it very slowly, mostly not until winter when the inflow of new amounts of material has ceased or the aquifer has frozen. Such differentiation can be observed by the formation of varved clays in the present-day glacial lakes and could somewhat tentatively be applied to explain the lamination of Kotlin clays as well. Differences in the thickness of seasonal layers can be explained by different sizes of local glacial dammed lakes and the Kotlin basin; i.e. by the distance

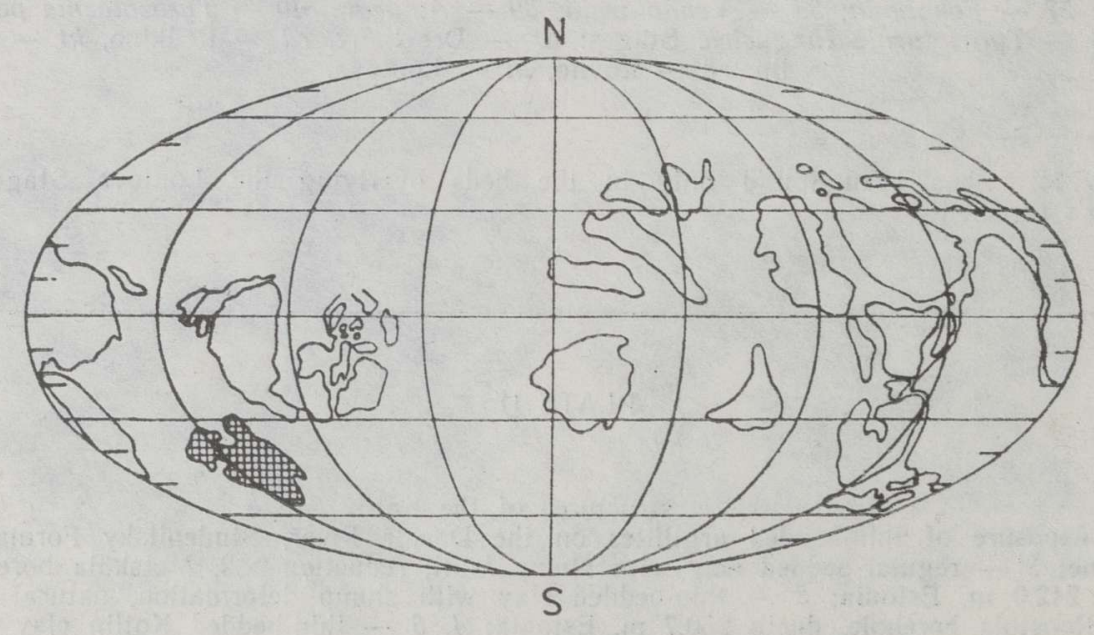

Fig. 2. Location of the East European Craton in the late Pre-Cambrian according to palinspastic reconstructions by Scotese et al. (1979). 
to the glaciation area. The notably bigger compactness of late Vendian clays should also be taken into account. This is in accordance with the location of eastern Europe at high latitudes of the Southern hemisphere on the plate tectonic reconstructions (Fig. 2). Extensive glaciation that took place in the early Vendian on the East European Craton (Чумаков, 1974) is also worthy of discussion.

Yet, there are two essential circumstances which may contradict the above-presented standpoints. Firstly, the extension of continuous strata of homogenous clays from Moscow to Moldova testifies to huge dimensions of the Kotlin Basin, laterally reaching to several thousands of kilometres (Fig. 3). For such a large basin we can hardly suggest a freshened sedimentary regime similar to that of glacial lakes. We may refer to the epicontinental nature of the basin and its small depth, but anyhow the inflow of the material should take place from various directions, hampering the formation of a distinct thin-bedded structure. Supposedly the surrounding glacial areas could have had similar gigantic dimensions.

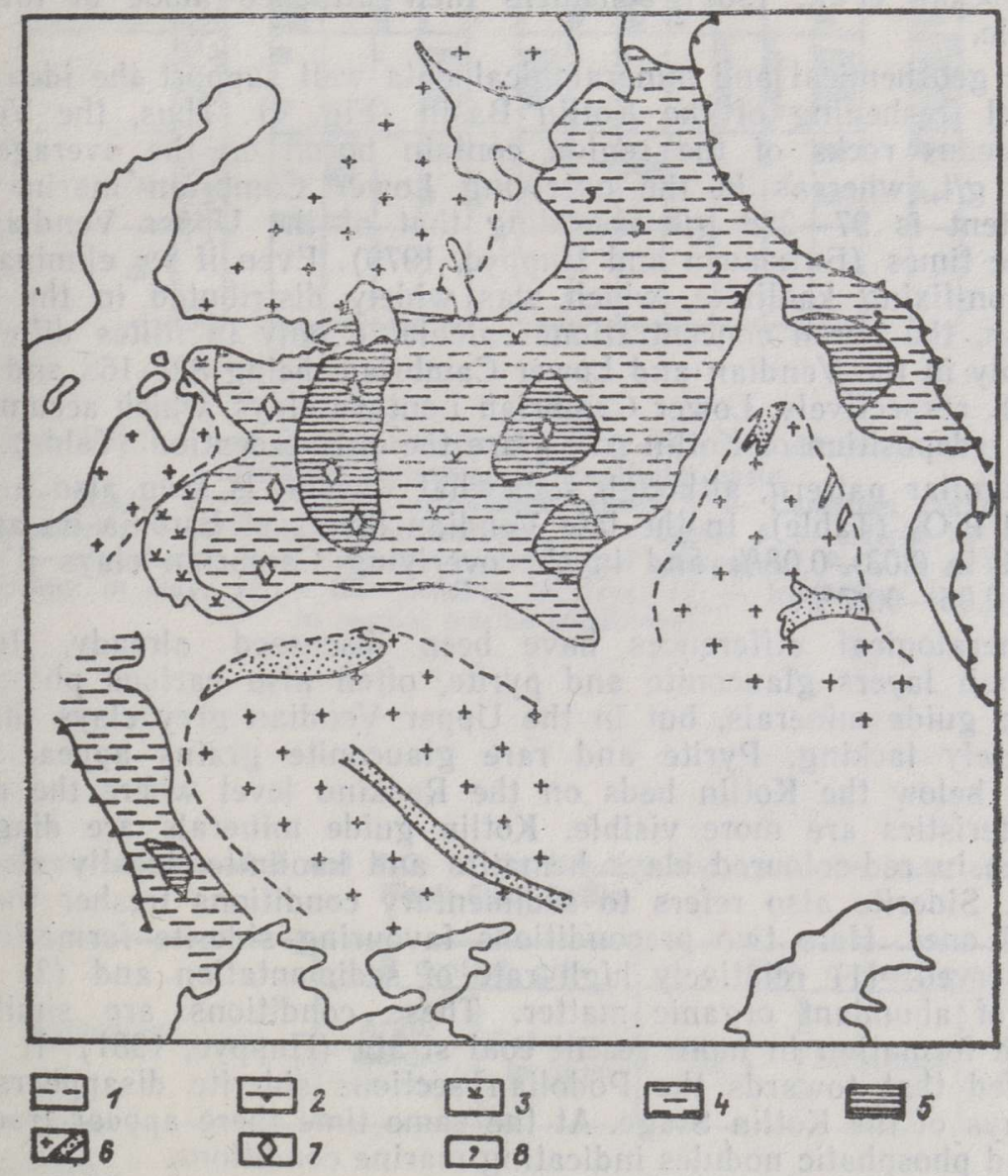

Fig. 3. Kotlin (Lyubim) paleogeographic map of the East European Craton after Aksyonov (Аксенов, 1987).

1 - supposed boundary of the basin on the craton; 2 - transition into the surround ing mobile zones; 3 - distribution of various red-coloured sediments; 4 - distribution of grey clays and siltstones; 5 - distribution of fine-dispersed clays; $6-$ cratonic source areas represented by crystalline rocks and Pre-Cambrian aulacogens; 7 - abundant siderite admixture; 8 - rare glauconite occurrences. 
It is also difficult to explain the occurrence of exuberant algal flora in this cold-water and turbid basin, rich in clay particles. The large number of well-preserved vendotaenids, in places also the abundance of dark organic matter occurring as films and dispersed nodules (on the average $0.5 \%$ ) well refer to the adaptation of the flora to this kind of a sedimentary basin. In the overlying noticeably warmer (glauconite!) Cambrian seas with clay accumulation these algae as well as organic films disappear immediately. The reason of the flourishing of Kotlin algal flora is still uncertain. This could have been due to the inflow of different nutrients from the fresh-water glaciers and particular burial conditions (rapid sedimentation). In Pleistocene glacier lakes the situation is the opposite. As a rule, they are very poor in organic matter in spite of a great variety of different organisms at this stage of the Earth's evolution. Considering the aforesaid, we can make two conclusions about the Kotlin vendotaenids. They were probably fresh-water forms and could not have been sessile benthos-dwellers. Here light substrate and limited photic conditions played the main restrictive role. Their anatomy has revealed no attachment organ, although Gnilovskaya (Гниловская et al., 1988) considers their attached mode of life very probable.

The geochemical and mineralogical data well support the idea about regional freshening of the Kotlin Basin (Fig. 4). Thus, the Vendian argillaceous rocks of the region contain boron on the average only $42-73 \mathrm{~g} / \mathrm{t}$, whereas in the overlying Lower Cambrian marine clays its content is $97-228 \mathrm{~g} / \mathrm{t}$ exceeding that of the Upper Vendian two to three times (Битюкова and Пиррус, 1979). Even if we eliminate the nonboron-fixing kaolinite, which was widely distributed in the Upper Vendian, the boron concentrations calculated only in illites differ considerably in the Vendian and Lower Cambrian, being 82-168 and 113$258 \mathrm{~g} / \mathrm{T}$, respectively. Lower Cambrian Lontova clays, which accumulated by the redeposition of Kotlin rocks, are the only exception (Table).

A similar pattern, although somewhat weaker, is seen also in background $\mathrm{P}_{2} \mathrm{O}_{5}$ (Table). In the late Vendian layers of Estonia its average content is $0.03-0.08 \%$ and in the overlying Cambrian clays it is, as a rule, $0.05-0.27 \%$.

Mineralogical differences have been discussed already. In the Cambrian layers glauconite and pyrite, often also various phosphates, are the guide minerals, but in the Upper Vendian grey clays they are completely lacking. Pyrite and rare glauconite grains appear immediately below the Kotlin beds on the Redkino level where the marine characteristics are more visible. Kotlin guide minerals are diagenetic siderite, in red-coloured clays hematite and kaolinite, locally also chamosite. Siderite also refers to sedimentary conditions fresher than the normal ones. Here two preconditions favouring siderite formation can be observed: (1) relatively high rate of sedimentation and (2) occurrence of abundant organic matter. These conditions are similar to siderite formation in more recent coal strata (Пиррус, 1981). It should be noted that towards the Podolian sections siderite disappears from the clays of the Kotlin Stage. At the same time there appear trace fossils and phosphatic nodules indicating marine conditions.

So, although the reasons of this phenomenon are still unclear, we should acknowledge an extensive inflow of freshened water to the late Vendian sedimentary basin on the East European Craton. This is particularly significant not only for the reconstruction of paleogeography, but also for understanding the fossil distribution and the application of stratigraphical correlations. We should draw also another important conclusion. The vendotaenid flora, which started to flourish in the late 
Vendian, seems to be of brackish-water character. This accounts for its rapid disappearance at the transition to the Early Cambrian and its certain endemic nature in general. These problems need further detailed paleontological investigation, keeping in view also ecological aspects (Fig. 4). The Kotlin sedimentary basin on the East European Craton deserves particular attention as an object for global paleogeographic reconstructions.
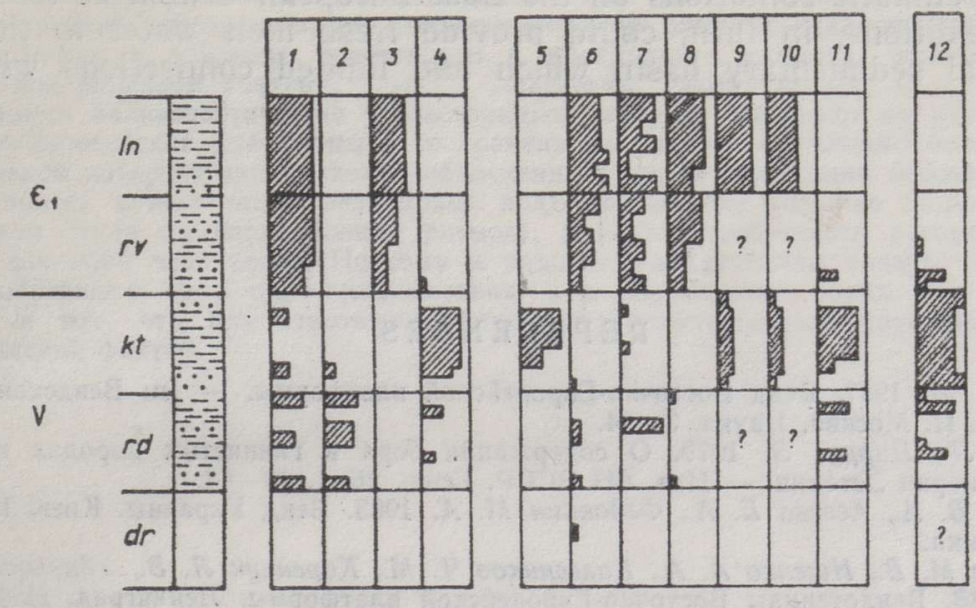

Fig. 4. Late Vendian and Early Cambrian biotic $(1-4)$ and abiotic $(5-11)$ features indicating freshening of the Kotlin basin.

1 - trace fossils; 2 - Vendian soft-bodied fauna; 3 - Cambrian fauna with a primitive skeleton (sabelliditids, platysolenids); 4 - algae; 5 - siderite; 6 - glauconite; 7 - phosphates; 8 - pyrite; 9 - content of background $\mathrm{P}_{2} \mathrm{O}_{5}$ in rocks; 10 boron content in clay; 11 - thin bedding of clays; 12 - freshening (as compared to normal marine conditions).

\section{Mean contents of $B$ and $P_{2} O_{5}$ in the Vendian and Cambrian rocks of North-East Baltic}

\begin{tabular}{|c|c|c|c|c|c|}
\hline \multirow[b]{2}{*}{ Formation } & \multicolumn{2}{|c|}{ B content, $\mathrm{g} / \mathrm{t}$} & \multicolumn{3}{|c|}{$\mathrm{P}_{2} \mathrm{O}_{5}$ content, $\mathrm{g} / \mathrm{t}$} \\
\hline & $\begin{array}{l}\text { Argil- } \\
\text { laceous } \\
\text { rocks }\end{array}$ & $\begin{array}{c}\text { Calculated } \\
\text { in illite }\end{array}$ & Clays & Siltstones & $\begin{array}{l}\text { Sand- } \\
\text { stones }\end{array}$ \\
\hline \multicolumn{6}{|l|}{ Lower Cambrian } \\
\hline $\begin{array}{l}\text { Tiskre Formation } \\
\text { Lükati Formation } \\
\text { Lontova Formation }\end{array}$ & $\begin{array}{r}181 \\
228 \\
97\end{array}$ & $\begin{array}{l}258 \\
253 \\
113\end{array}$ & $\begin{array}{l}1600 \\
2100\end{array}$ & $\begin{array}{r}900 \\
800 \\
1600\end{array}$ & $\begin{array}{r}500 \\
1300\end{array}$ \\
\hline \multicolumn{6}{|l|}{ Upper Vendian } \\
\hline $\begin{array}{l}\text { Voronka Formation } \\
\text { Kotlin Formation } \\
\text { Gdov Formation }\end{array}$ & $\begin{array}{l}56 \\
73 \\
42\end{array}$ & $\begin{array}{r}168 \\
85 \\
82\end{array}$ & $\begin{array}{l}700 \\
300\end{array}$ & $\begin{array}{l}600 \\
800\end{array}$ & $\begin{array}{l}600 \\
400\end{array}$ \\
\hline
\end{tabular}


Freshening, which reached its maximum in the Kotlin time, was not an extraordinary or nonrecurrent process. Judging by the thin-bedded grey clay layers containing organic plant remains, these conditions formed episodically already in the Redkino time, usually at the terminal stages of its subcycles. Unlike Kotlin clays, these beds are usually rich in organic matter, never containing siderite. Also in the Lower Cambrian, e.g. the Toropets core section near Velikiye Luki, the Rovno Stage sometimes yields thin-bedded clayey rocks devoid of vendotaenids but often sandwiched by typical marine sediments. This shows that seasonal rhythmicity has been caused by very strong factors, appearing and retreating gradually. Therefore they can be treated as a reflection of severe climatic conditions on the East European Craton at that time. These conditions, in turn, could provide fresh melt water to the epicontinental sedimentary basin which had limited connections with the ocean.

\section{REFERENCES}

Аксенов E. M. 1987. Венд Восточно-Европейской платформы. - In: Вендская система, II. Москва, Наука, 3-34.

Битюкова Л., Пиррус Э. 1979. О содержании бора в глинистых породах венда и кембрия Эстонии. - Изв. АН ЭССР. Геол., 28, 1, 40-42.

Великанов B. A., Асеева E. A., Федонкин M. A. 1983. Венд Украины. Киев, Наукова думка.

Гниловская М. Б., Ниценко А. А., Колесников Ч. М., Коренчук Л. В., Удальцов А. П. 1988. Вендотениды Восточно-Европейской платформы. Ленинград, Наука.

Менс K. А., Пиррус Э. А. 1974. Вендские отложения Прибалтики и литогенетические особенности их формирования. - In: Тезисы докладов совещания по верхнему докембрию (рифею) Русской платформы. Москва, 84-88.

Пиррус Э. А. 1981. Сидеритовая мннерализация в котлинской свите - характерный процесс диагенеза в поздневендских глинах. - In: Аутигенные минералы терригенных отложений Прибалтики. Таллинн, АН ЭССР, 56-77.

Стратиграфия верхнедокембрийских и кембрийских отложений запада Восточно-Европейской платформы. 1979. Москва, Наука.

Федонкин M. A. 1987. Бесскелетная фауна венда и ее место в эволюции метазоа. Москва, Наука.

Чумаков Н. М. 1974. Лапландское оледенение. - In: Этюды по стратиграфии. Москва, Наука, 71-96.

Scotese, C. R., Bambach, R. K., Barton, C., Van der Voo, R., Ziegler, A. M. 1979. Paleosoic base map. - J. Geol., 87, 3, 217-227.

Presented by A. Raukas

Received

Feb. 25, 1992

Enn PIRRUS

\section{HILISVENDI BASSEINI REGIONAALSEST MAGESTUMISEST IDA-EUROOPA PLATVORMIL}

On näidatud, et skeletita faunafossiilide levik Ida-Euroopa ülemvendi vertikaalläbilõikes on rangelt stratifitseeritud ja vastupidine vetikafloora jaotumusele, seejuures otseses seoses ka hüdrokeemilist, eeskätt soolsusrežiimi kajastavate indikaatormineraalide glaukoniidi, fosfaadi, püriidi ja sideriidi - sisaldusega ümbriskivimis. See lubab teha järelduse, et hilisvendis leidis aset Kotlini hiidbasseini ulatuslik magestumine, mida markeerib riimveelise vetikafloora vohamine ja sideriidi teke savisetete diageneesil. Järeldust kinnitab ka geokeemiline andmestik, eeskätt $\mathrm{B}$ ja $\mathrm{P}_{2} \mathrm{O}_{5}$ madal sisaldus käsitletaval tasemel. Normaalmerelisest erinev settimiskeskkond seletab kõige paremini ka Kotlini savide tekstuurse iseärasuse - väljapeetud peenekihilisuse, mis ühtlasi viitab ka jahedatele kliimaoludele ning on heas kooskõlas ettekujutusega Ida-Euroopa platvormi paiknemisest hilisvendis löunapooluse lähikonnas. 


\section{РЕГИОНАЛЬНОЕ ОПРЕСНЕНИЕ КОТЛИНСКОГО БАССЕЙНА ПОЗДНЕГО ВЕНДА НА ВОСТОЧНО-ЕВРОПЕИСКОЙ ПЛАТФОРМЕ}

Показано, что в разрезе Восточно-Европейской платформы остатки бесскелетной фауны установлены только в редкинском горизонте нижней части верхнего венда, в то время как богатые находки водорослей-вендотенид связаны, главным образом, с вышележащим котлинским горизонтом. Стратифицированы в разрезе и аутигенные минералы, отражающие гидрохимические условия седиментации. Для котлинского горизонта характерен сидернт, для редкинского - пирнт, глауконит, фосфаты. В котлинских отложениях отмечается также очень низкое содержание бора и фосфора, Совокупность всех этих данных подводит к выводу о сильном опреснении котлинского бассейна в пределах платформы, что, в свою очередь, наилучшим образом объясняет выдержанную тонкую слонстость котлинских глин. Эта их текстурная особенность явилась, по всей вероятности, результатом сезонной ритмики осадконакопления, возможной только в условиях пресноводья и прохладного климата, установившегося, видимо, под влиянием континентального оледенения, Такому выводу не противоречат и имеющиеся палинспастические реконструкции, которые указывают на расположение Восточно-Европейской платформы в те времена на близких от южного полюса широтах. В такой интерпретации находят объяснение причина опреснения бассейна (интенсивный приток в него талых ледниковых вод), необычайно большие скорости глинонакопления (судя по числу тонких ритмов), а также особенности распределения в разрезе фоссилий всех типов. Поэтому и водоросли-вендотениды следует относить к флоре, обитавшей не в нормально-морских, а в опресненных водах. Все сказанное говорит о том, что при стратиграфнческой корреляции нельзя упускать из вида экологический фактор. 